KEMAS 14 (1) (2018) 56-61
Jurnal Kesehatan Masyarakat

\title{
Parity and Maternal Illness and the Incidence of Imminent Abortion
}

\author{
Layla Fadhilah Rangkuti ${ }^{1 凶}$, Delfi Lutan², Sri Rahayu Sanusi ${ }^{3}$ \\ ${ }^{1}$ Public Health Master Program, Public Health Faculty, Universitas Sumatera Utara \\ ${ }^{2}$ Obstetry and Ginecology Departement, Faculty of Medicine, Universitas Sumatera Utara \\ ${ }^{3}$ Department of Population and Biostatistics, Public Health Faculty, Universitas Sumatera Utara
}

\begin{tabular}{l} 
Article Info \\
\hline Article History: \\
Submitted September 2017 \\
Accepted January 2018 \\
Published July 2018 \\
\hline Keywords: \\
Pregnant Women, \\
Imminent Abortion, \\
Parity, Maternal Illness \\
\hline DOI \\
https://doi.org/10.15294/ \\
kemas.v14i1.11166
\end{tabular}

\begin{abstract}
Imminent abortion is the first stage abortion and a threat of abortion. Most of the studies stated that the incidence of abortion is $15-20 \%$ of all pregnancies. Complication in imminent abortion is bleeding or infection which can cause mortality. The objective of this research was to analyze the relationship of parity and maternal illness with the incidence of imminent abortion. The research used observational analytic study with case-control design. The samples were 100 participants. The data were analyzed by using univariate analysis and bivariate analysis with chi square test. The result of the bivariate analysis with chi square test showed that there was significant association of parity $(\mathrm{p}=0.0001)$ and maternal illness $(\mathrm{p}=0.0001)$ on the incidence of imminent abortion. It is recommended that health care providers can detect abortion earlier and also provide counseling for pregnant women about imminent abortion.
\end{abstract}

\section{Introduction}

Health problem is an important issues faced by society nowadays, especially that happened to women. Women reproductive health is a very important thing to consider because women is a unique creatures. Women experience some of life stage in their life cycle, among of them are pregnant and giving birth.

According to the World Health Organization (WHO), the five biggest causes of maternal deaths are bleeding, hypertension in pregnancy, infection, obstructed labour, and abortion. Maternal death in Indonesia is still dominated by three major causes of death: bleeding, hypertension in pregnancy and infection (Kurniawan, 2016).

In their life cycle, women experience stages of life, among of them which is pregnant and give birth. Some of pregnancy terminate at birth, but some of them is not uncommon experience abortion. Abortion is defined as the expulsion of the conception before viable to live outside the womb with weight less than 1000 grams or gestational age less than 28 weeks (Rukiyah, 2010).

Imminent abortion is the occurrence of bleeding spot that indicate a threat to the survival of the pregnancy. Under these conditions, pregnancy may still persist or be maintained, characterized by bleeding either spotting or moderate bleeding, closed cervix (because at the vaginal examination there is no opening of the OUE), uterus fit the gestational age, lower abdominal cramp, twisting pain due to no or very slightly contraction, no cervix abnormalities (Rukiyah, 2010).

Imminent abortion is the most common complication of pregnancy and causes serious emotional burden, occurs in one of five cases and increase the risk of miscarriage, premature 
birth, low birth weight (LBW), perinatal death, antepartum bleeding and premature rupture of membrane (PROM) but no risk of disabled baby. Diagnose of imminent abortion determined by the occurrence of bleeding at early pregnancy through the external uterine opening (OUE), with little or no abdominal pain, closed cervix and the fetus alive (Ilhaini, 2013).

Cases abortion, an average of 114 times in 1 hour. Most studies suggest abortion occurrence between $15-20 \%$ of all pregnancies. If studied furthermore, the incidence of abortion may be close to $50 \%$. This is due to the high of the chemical pregnancy loss number which not known at 2-4 weeks after the conception. Most of these pregnancy failure are due to gametes failure, such as sperm and oocyte dysfunction (Prawirohardjo, 2014).

WHO estimates that 4.2 million abortions are conducted annually in Southeast Asia, the detail is 1.3 million in Vietnam and Singapore, 750.000 - 1.5 million in Indonesia, 155.000 - 750.000 in Philippines and 300.000 900.000 in Thailand (Hamidah, 2013).

In the United States, the incidence of abortion nationally range $10-20 \%$. According to the Ministry of Health Indonesia, Indonesia abortion is a second cause of maternal death (26\%). In Indonesia, there are 43 cases of abortion per 100 thousand live birth. The incidence of abortion in Indonesia is the highest in Southeast Asia, that is as much 2 million out of 4.2 million cases (Rahmani, 2014).

In Indonesia, maternal death according to the Indonesia Demographic Health (SDKI) 2012 increase to the 359 death per 100.000 live birth. The incidence of abortion in Indonesia 2 million cases in a year. That is means there are 43 cases of abortion per 100 live birth (Hamidah, 2013).

According to the BKKBN from the report of Australian Consortium For Country Indonesian Studies (2013) shows the result of research in 10 major cities and 6 district in Indonesia occurred 43 of abortion per 100 live birth. That abortion was committed by women in urban areas by $78 \%$ and women in rural area $40 \%$. Women who have abortions in large city in Indonesia commonly are teenager age 15-19 years. Generally, that abortion is done due to unwanted pregnancy (Wadud, 2012).
The result of research by Hamidah in Cipto Mangunkusumo General Hospital in 2013 stated that age, parity, gestational age and abortion history related to the imminent abortion. Education variable are not related to the imminent abortion. Multivariate analysis stated that parity $>3$ risk 6.9 greater than parity $1-3$. Ages $<20$ and $>35$ are 4 times greater than age 20-35 years, abortion history is 4.2 greater than women without abortion history. Parity is a dominant risk factor for the incidence of the imminent abortion (

A study by Mursyida stated that there was significant relationship between parity and the incidence of imminent abortion from the statistical test obtained p-value $=0.002$ in midwifery hospitalization service at Muhammadiyah Hospital Palembang (Wadud, 2012). According to the Yakistiran et al, which studied 493 patients with imminent abortion who treated in Department of Obstetrics and Gynecology, Faculty of Medicine Ankara University Turkey between 2007 and 2015, there was an adverse effect of maternal age and abortion history with imminent abortion and the risk of premature baby, abortion, low birth weight and premature rupture of membrane at imminent abortion group (Yakistiran et al., 2016).

According to the previous research variable, there are several factor related to the incidence of imminent abortion, one of them is parity. However, the authors interested to add the variable of maternal illness because in the previous study there has been no research about the relationship of maternal disease with the occurrence of imminent abortion.

Almost $50 \%$ of pregnancies end in miscarriage, if a pregnancy continues the fetus delivered will have adverse effect such as premature birth, premature rupture of membrane, preeclampsia, placenta; abruption, intrauterine growth restriction (IUGR) may occur. It is well known that maternal age, systemic disease such as diabetes mellitus, hypothyroidism, infertility treatment, thrombophilia, maternal weight and abnormal uterine structure will increase the risk of imminent abortion (Yakistiran et al., 2016).

The risk of abortion will increase as parity and age increase. At multiparity 
pregnancy, the endometrial environment around the implantation site is less perfect and is not ready to accept the conception so that provision of nutrient and oxygenation will be less perfect and caused the growth of conception is disrupted. This is in accordance with the Meclicine's opinion that women with high parity (more than 3 times) are more likely to have complication at the pregnancy and will have an effect to the delivery (Wadud, 2012).

Maternal disease such as infectious disease that cause high fever due to pneumonia, typhoid, pyelitis, rubella, malta fever etc; fetal death can be caused by maternal toxin or germ and virus invasion of the fetus; $\mathrm{Pb}$ poisoning, nicotine, toxic gas, alcohol, etc.; the maternal asphyxia such as decompensation of the cord, severe lung disease, anemia gravis, malnutrition, avitaminosis and metabolic syndrome, hypothyroidism, vitamin A, C or E deficiency and diabetes mellitus are also factors that cause imminent abortion (Yakistiran et al., 2016).

At the healthy reproductive period, it is known that safe age for pregnancy, labor and birth is 20-34 years. The frequency of abortion is clinically increased by $12 \%$ in women younger than 20 and $26 \%$ in women over 40 years. The risk of abortion increase with parity. Parity more than 3 is a high risk of abortion (Rukiyah, 2010).

Abortion can be experienced by all pregnant women, risk factor include age and history of recurrent abortion. Age may affect recurrent abortion occurrence because at the age of less than 20 years, the reproductive organ is still immature to pregnant so that can adverse maternal health and fetal growth and development, whereas abortion occurring at the age more than 35 years is due to decrease in reproductive function, chromosomal abnormalities and chronic disease (Rahmani, 2014).

As it is known that the main cause of maternal death is bleeding, infection and infection but actually abortion is also the cause of maternal death, but it is only appears in the form of bleeding and sepsis. Although it is generally acknowledged that maternal death caused by complication of abortion do not often appear in the death report in the vital statistical system in the United Stated but there is almost 200 countries which are abortion procedure are legalized and estimated almost 45-50 million cases reported every year in the entire world, but there is no country reports abortion complication as death. The higher rates of abortion may increase maternal morbidity and even maternal mortality (Studnicki et al., 2016).

Imminent abortion is the most pregnant complication and cause serious emotional burden, which can increase the risk of abortion, premature birth, low birth weight (LBW), perinatal death, antepartum hemorrhage, and premature rupture of membrane (PROM). If imminent abortion is not given appropriate treatment and appropriate procedure, there will be complication that cause increase maternal morbidity rate. And if that complication is not handled properly then it could cause maternal death that will increase the maternal mortality rate. Information obtained by mother in general practice or other health service is too low, this is the reason why abortion occurs and its consequences will occurs in the future of pregnancy (Ilhaini, 2013).

Regional General Hospital (RSUD) Padangsidimpuan City is one of the largest health facility in Padangsidimpuan City. Padangsidimpuan City General Hospital is also a referral hospital from all areas of Goverment Padangsidimpuan. Incidence of abortion in 2015-2016 are 192 cases consisting of imminent, incomplete, complete, missed, and incipient abortion. Out of 192 cases, 50 of them were imminent abortion. Based on that background, the authors are interested to analyze the relationship of parity and maternal disease with the incidence of imminent abortion in Regional General Hospital of Padangsidimpuan City at the period of 2015-2016.

\section{Method}

We used observational analytic study with case control design. Analytical survey was a survey or research that tried to explore how and why the health phenomenon occurs. We then performed dynamic correlation analysis between phenomena or among risk factors and effect factors. The meaning of effect factors is a consequences of a risk factors, while the risk factors is a phenomenon that resulted in an effect (influence). 
In a case control, research began with the identification of patients with certain effects or disease (called cases) and group without effect (called control). Then risk factor that can explain why the case was affected while the control was not were traced retroactively. This research assessed the effect of factors with the incidence of abortion using the methods of determining case and control groups, then measuring the magnitude of the risk (frequency of exposure) in both groups.

This research was conducted in Padangsidimpuan Regional General Hospital by using medical record data of mothers who diagnose with imminent abortion by the doctors at the period of January 2015 to December 2016. Variable observed in this research was parity and mother's disease.

Analytical data methods used include univariate analysis that explain or described the characteristic of each research variables. The form of univariate analysis depended from the type of the data. The numerical data used mean, median and standard deviation. Generally in this analysis just produced the frequency distribution and percentage of the each variables. And bivariate analysis with chi-square was by looking from the result of this statistical test will be able to deduced the existence of relationship of two variables were significant or not. The statistic test result can occurs when two variable were percentage related but statistically the relationship was not significant. The time of this study started from March to July 2017.

\section{Results and Discussion}

The Chi-square analysis indicated that there was an association between parity and imminent abortion $(p=0.0001)$ in which the women in group cases have 5.5 times higher risk compared to control group (odds ratio: 5.52).

There were 37 (74\%) pregnant women with parity status $<1$ and $\geq 4$ who experienced imminent abortion. Approximately, more parity lead to weaker and tenuous uterus. A mother who had deliveries $\geq 4$ times had to more cautious about any disorders developed during pregnancy, labor, and puerperal stage. The risk of abortion was higher with increasing parity and age. The endometrium in multi-parity were poor oxygenation and lack of nutrients provision which was not ready to accept the conception and inhibit conception growth. This was consistent with a study by Meclicine which revealed that women with high parity (giving labor more than 3 times) tend to have complication during pregnancy and labor.

The Odd Ratio of parity from multivariate analysis was 6,304 which means women in parity group had a chance of 6.3 times to experience imminent abortion. Fetus development in multi-parity women often has disturbance due to degenerative process in mother.

The assumption was that the higher the parity the higher the incidence of abortion and conversely the lower the parity the lower events of abortion. Several dangerous complications of abortion were bleeding, perforation, infection,

Table 1. The Distribution of Relationship between Parity and Imminent Abortions in Regional Public Hospital Padangsidimpuan City

\begin{tabular}{|c|c|c|c|c|c|c|}
\hline \multirow{3}{*}{ Parity } & \multicolumn{4}{|c|}{ Abortion Imminent } & \multirow{5}{*}{$\begin{array}{l}\text { OR } \\
(95 \% \mathrm{CI}) \\
\\
5.52 \\
(2.33-13.07)\end{array}$} & \multirow{4}{*}{$\begin{array}{l}\chi^{2 / P} \text { value } \\
16.103 / 0.0001\end{array}$} \\
\hline & \multicolumn{2}{|c|}{ Positive } & \multicolumn{2}{|c|}{ Negative } & & \\
\hline & $\mathrm{n}$ & $\%$ & $\mathrm{n}$ & $\%$ & & \\
\hline$<1$ dan $\geq 4$ & 37 & 74.0 & 17 & 26.0 & & \\
\hline $1-3$ & 13 & 26.0 & 33 & 74.0 & & \\
\hline $\begin{array}{l}\text { Maternal } \\
\text { disease }\end{array}$ & & & & & & \\
\hline Exist & $\begin{array}{l}39 \\
11\end{array}$ & $\begin{array}{l}78.0 \\
22.0\end{array}$ & $\begin{array}{l}6 \\
44\end{array}$ & $\begin{array}{l}12.0 \\
88.0\end{array}$ & $\begin{array}{l}26.0 \\
(8.79-76.8)\end{array}$ & $41.374 / 0.0001$ \\
\hline $\begin{array}{l}\text { None } \\
\text { Total }\end{array}$ & 50 & 100.0 & 50 & 100.0 & & \\
\hline
\end{tabular}

Source : Primary Data 
and shock. In addition, abortion give rise to psychological changes including conflict in decision-making, being ambivalent and hesitant in making decisions, feeling pressured or coerced, feeling powerless to decide or feel entitled to vote.

This research was consistent with Hamidah's study in Cipto Mangunkusumo General Hospital Jakarta which revealed that the proportion of imminent abortion in women with parity state $<1$ and $\geq 3$ was $13 \%$. The research also stated that there was relationship between parity and imminent abortion $(\mathrm{p}=0.049)$. In addition, multivariate analysis of women who had parity $\geq 3$ showed that they had risk 6.9 times higher than women who had parity 1-3.

Moreover, this study was consistent with two similar study, i.e. Wadud's study in inpatient midwifery installation of Muhammadiyah Palembang and $\mathrm{Hj}$. Husna's study in Lamadukkelleng Sengkang Regional Public Hospital, Wajo Regency which also elucidated that there was significant relationship between parity and imminent abortion ( $p$ value $=0.0002$ and $p$ value $=0.000$ consecutively). The Odd Ratio (OR) was 2.917, which means women in high risk parity group 2.917 times had chance to experience abortion than in low risk parity group.

According to Wiknjosastro, parity refer to the number of children given birth from a mother regardless of whether the child was born alive or was stillborn. It was known that 2-3 parity was the most secure parity who had least maternal death risk. Parity 1 and $\geq 3$ had higher maternal death risk. The risk in parity 1 could be reduced by better obstetric care, whereas the risk in higher parity could be prevented with family planning. The fact is almost of pregnancy in high parity was unplanned pregnancy.

In this research, imminent abortion also experienced by mother in low parity risk since it can be occurred in every pregnancy without proper obstetric care. If the risk in primigravida was reduced, that the pregnancy can be reached aterm stage. High risk multiparity $(\geq 4)$ was caused by decreased in reproductive function and could be prevented with family planning.

This study analyzed that there was an association between parity and maternal disease $(p=0,0001)$ in which the women in group cases have 26 times higher risk to develop imminent abortion compared to control group (odds ratio: 26 ).

There were $39(78 \%)$ pregnant women who had certain disease experienced imminent abortion. Disease occupied by the mother could exacerbate the fetus condition, for example, the placental oxygenation would be disturbed in a mother who had endarteritis in her chorionic villi and the fetus growth would be disturbed even being stillborn. This condition could be happened since early pregnancy due to chronic hypertension.

Several diseases could directly inhibit fetus growth through placenta, including infection disease: pneumonia, abdominal typhoid, malaria, and syphilis; anemia; and chronic disease such as: hypertension, chronic kidney disease, liver disease, and type II diabetic.

Stillborn fetus might due to toxin or direct invasion of bacteria or viruses in various diseases which caused high fever such as pneumonia, typhoid, pyelitis, rubella, malta fever, etc. Moreover, there were several factors influencing imminent abortion which were poisoned by some materials (lead, nicotine, poison gas, alcohol, etc.), chronic asphyxia condition (cardiac decompensate, chronic obstructive pulmonary disease, and anemia gravis), malnutrition, avitaminosis, metabolic disorder, hypothyroid, deficiency vitamin A, C, or E, and type II diabetic.

Multivariate analysis revealed Odd Ratio of parity group was 27.936 which means mother suffered from certain disease had chance to experience imminent abortion 27.9 times higher than mother who had do disease.

Almost $50 \%$ of pregnancy was ended by abortion, or if the pregnancy was continued, it would result on preterm labor, premature rupture of membranes, preeclampsia, placental solution, and Intrauterine Growth Restriction (IUGR). It is known that mother's age, systemic disease specifically type II diabetic, hypothyroidism, infertility treatment, thrombophilia, mother's weight, and abnormal uterine structure can increase the risk for developing imminent abortion.

Mother suffered from certain disease 
had several risks to get abortion, preterm labor, low birth weight, antepartum hemorrhage, premature rupture of membrane, and stillborn. Routine obstetric examination, sufficient rest, and high nutrient food were needed to take care of the pregnancy (Triana, 2015).

High risk pregnant women should look after their own health not to get sick, perform routine obstetric examination, and routine health check-up every month to anticipate baby and the mother from any harmful event.

Pregnant women should maintain their intake by eating nutritious food and balance diet to prevent hypertension. Moreover, light exercise including walking and swimming, and enriched knowledge about high risk pregnancy could be very helpful to avoid unwanted events (Lubis, 2017).

\section{Conclusions}

The study find that there is a relationship between parity as well as maternal disease and imminent abortion in regional general hospital in Padangsidimpuan.

Various recommendations for high risk pregnant women to avoid harmful event of both, the baby and the mother are look after their own health and perform routine obstetric examination. The midwife and obstetrician are expected to increase their own knowledge and skill as well as provide counselling in order to detect imminent abortion earlier.

\section{References}

Hamidah, 2013. Faktor Dominan yang Berhubungan Dengan Kejadian Abortus Imminens. Jurnal Ilmu \& Teknologi Ilmu Kesehatan, 1(2), pp.29-33.
Ilhaini, N., 2013. Abortus Imminens: Upaya Pencegahan, Pemeriksaan, dan Penatalaksanaan. Majalah Cermin Dunia Kedokteran, 40 (7).

Kurniawan, A., 2016. Early Detection of High Risk Pregnancy. Jurnal Kesehatan Masyarakat, 12(2), pp.96-103.

Lubis, Z., 2017. Karakteristik, Asupan Gizi dan Kejadian Anemia pada Ibu Hamil. Jurnal Media Kesehatan Masyarakat Indonesia, FKM UNHAS, 13 (3), pp.224-229.

Prawirohardjo, S., 2014. Ilmu Kebidanan. Jakarta: Bina Pustaka Sarwono Prawirohardjo.

Rahmani, S.L., 2014. Faktor-Faktor Risiko Kejadian Abortus Di RS Prikasih Jakarta Selatan Pada tahun 2013. Jurnal Ilmu \& Teknologi Ilmu Kesehatan, 2(1), pp.13-21.

Rukiyah, Yeyeh, A., Yulianti, L., 2010. Asuhan Kebidanan 4 (Patologi Kebidanan). Jakarta: Trans Info Medika.

Studnicki, J., MacKinnon, S.J., Fisher, J.W., 2016. Induced Abortion, Mortality, and the Conduct of Science. Scientific Research Publishing. Open Journal of Preventive Medicine, 6, pp.170-177.

Triana, A., 2015. Faktor Determinan Toksoplasmosis Pada Ibu Hamil. Jurnal Kesehatan Masyarakat, 11 (1), pp. 25-31.

Wadud, M., 2012. Faktor-Faktor Yang Berhubungan Dengan Kejadian Abortus Imminens Di Instalasi Rawat Inap Kebidanan Rumah Sakit Muhammadiyah Palembang Tahun 2011. Jurnal Ilmu \& Teknologi Ilmu Kesehatan, 2(1), pp.21-25.

Yakıştıran, B., Yüce, T., Söylemez, F., 2016. First Trimester Bleeding and Pregnancy Outcomes: Case-Control Study. International Journal of Women's Health and Reproduction Sciences, IJWHR, 4(1), pp. 4-7 